\title{
(6) OPEN ACCESS \\ Abusive head trauma and accidental head injury: a 20-year comparative study of referrals to a hospital child protection team
}

\author{
Patrick Kelly, ${ }_{1}^{1,2}$ Simon John, ${ }^{3}$ Andrea L Vincent, ${ }^{4,5}$ Peter Reed $^{6}$
}

\begin{abstract}
${ }^{1}$ Te Puaruruhau (Child Protection Team), Starship Children's Hospital, Auckland District Health Board, Auckland, New Zealand ${ }^{2}$ Department of Paediatrics, Faculty of Medical and Health Sciences, University of Auckland, Auckland, New Zealand

${ }^{3}$ Department of Neurosurgery, Christchurch Hospital, Canterbury District Health Board, Christchurch, New Zealand

${ }^{4}$ Department of Ophthalmology, Auckland District Health Board, Auckland, New Zealand ${ }^{5}$ Department of Ophthalmology, New Zealand National Eye Centre, Faculty of Medical and Health Sciences, University of Auckland, Auckland, New Zealand ${ }^{6}$ Children's Research Centre, Starship Children's Hospital, Auckland District Health Board, Auckland, New Zealand
\end{abstract}

\section{Correspondence to} Dr Patrick Kelly, Te Puaruruhau (Child Protection), Starship Children's Hospital, Park Road, Private Bag 92024 Auckland 1, New Zealand patrickk@adhb.govt.nz

Received 12 June 2014 Revised 20 April 2015 Accepted 28 May 2015 Published Online First 30 June 2015

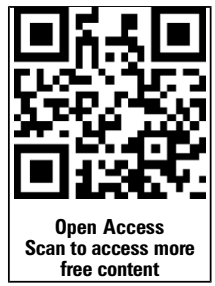

CrossMark

To cite: Kelly $P$, John $S$, Vincent AL, et al. Arch Dis Child 2015;100

1123-1130.

\section{ABSTRACT}

Aim To describe children referred for suspected abusive head trauma (AHT) to a hospital child protection team in Auckland, New Zealand.

Methods Comparative review of demographics, histories, injuries, investigations and diagnostic outcomes for referrals under 15 years old from 1991 to 2010.

Results Records were available for 345 children. Referrals increased markedly (88 in the first decade, 257 in the second), but the diagnostic ratio was stable: AHT $60 \%$, accidental or natural $29 \%$ and uncertain cause $11 \%$. The probability of AHT was similar regardless of socio-economic status or ethnicity. In children under 2 years old with accidental head injuries (75/255, 29\%) or AHT $(180 / 255,71 \%)$, characteristics of particular interest for AHT included no history of trauma (88/98, $90 \%)$, no evidence of impact to the head $(84 / 93,90 \%)$, complex skull fractures with intracranial injury (22/28, $79 \%)$, subdural haemorrhage $(160 / 179,89 \%)$ and hypoxic ischaemic injury $(38 / 39,97 \%)$. In children over 2 years old, these characteristics did not differ significantly between children with accidental head injuries $(21 / 47,45 \%)$ and AHT $(26 / 47,55 \%)$. The mortality of AHT was higher in children over 2 years old $(10 / 26,38 \%)$ than under 2 years $(19 / 180,11 \%)$.

Conclusions The striking increase in referrals for AHT probably represents increasing incidence. The decision to refer a hospitalised child with a head injury for assessment for possible AHT should not be influenced by socio-economic status or ethnicity. Children over 2 years old hospitalised for AHT are usually injured by mechanisms involving impact and should be considered at high risk of death.

\section{INTRODUCTION}

Head injuries are common in child abuse, ${ }^{1}{ }^{2}$ and abusive head trauma (AHT) is the leading cause of fatal head injury in children under 2 years old. ${ }^{3}$

The fact that the most serious AHT occurs in infancy is challenging. Infants may have nonspecific symptoms, no bruising and no history of trauma. ${ }^{4} 5$ AHT is often denied and may result in controversial legal proceedings. ${ }^{6-8}$

There is no gold standard diagnostic test for AHT. Because best practice relies on a careful multidisciplinary approach, ${ }^{9}{ }^{10}$ there has been a specialist child protection team in New Zealand's national children's hospital since 1991.

The objectives of this study were to describe and compare the characteristics of accidental head injury and AHT in a large cohort of children comprehensively evaluated for suspected AHT, and thus

\section{What is already known on this topic}

Abusive head trauma (AHT) is the leading cause of fatal head injury in children under 2 years old.

- There are no pathognomonic diagnostic features of AHT.

- The diagnosis of AHT is a complex and demanding area of clinical paediatrics and requires a meticulous multidisciplinary approach.

\section{What this study adds}

- In Auckland, New Zealand, there appears to have been an increase in the incidence of AHT over time.

- Regardless of ethnicity or socio-economic status, head-injured children referred by hospital staff are at high risk of meeting criteria for AHT.

- Children over 2 years old hospitalised for AHT have a different pattern of injury from younger children and are at higher risk of death.

add to the observational data available to other clinicians who may need to evaluate cases of suspected AHT.

\section{METHODS}

This retrospective review was approved by the Health and Disability Ethics Committee and conducted in Auckland, New Zealand. Starship Children's Hospital is the Level One paediatric trauma centre for New Zealand (population 4.4 million). Auckland is the largest city (population 1.4 million), and $37 \%$ of children are Polynesian (18\% indigenous Maori, 19\% other Pacific peoples). ${ }^{11}$

\section{Inclusion criteria}

Referral to the child protection team from January 1991 to December 2010 and skull fracture or intracranial injury. Not all head injuries are referred, only those where the primary team is concerned about possible AHT.

\section{Child protection team}

Known as Te Puaruruhau (Maori for 'sheltering the bud'), the team comprises paediatricians, nurses 
and social workers. Inpatients are seen only on referral from the primary team. There are no fixed referral criteria, but consultation is encouraged for any concern about inflicted injury. Clinical approach and key personnel have been consistent since 1991.

\section{Child protection assessment}

There is joint assessment by a consultant paediatrician and hospital social worker, meticulous re-taking of the history, detailed physical examination and additional investigations as indicated. Investigations are reviewed with appropriate subspecialists, including radiology side-by-side with paediatric radiologists and neuroradiologists. Findings and differential diagnoses are discussed with the primary team. Further investigations and second opinions are sought where indicated, and all assessments receive weekly multidisciplinary peer review.

\section{Radiology}

Skeletal surveys are routine in children under 2 years unless there is a clear history consistent with the injury, but are performed selectively in older children. Acute presentations receive two skeletal surveys. ${ }^{12}$ CT head scans accompany skeletal surveys in infants under 1 year, and in older children if intracranial injuries are suspected. MRIs were introduced in 1995, and by 2000 were usual practice if the CT was abnormal. Neuroradiology is reported by subspecialist neuroradiologists.

\section{Ophthalmoscopy}

Consultant paediatric ophthalmologists perform indirect ophthalmoscopy through dilated pupils. Retcam photography (Clarity Medical Systems, Pleasanton, California, USA) was added for documentation in 2001, but did not change the diagnostic process.

\section{Autopsy}

When a hospitalised child dies from suspected AHT, the Te Puaruruhau paediatrician usually attends the autopsy.

\section{Diagnostic outcomes}

All cases diagnosed as AHT, or where the diagnosis is unclear, are notified to the statutory authorities for further investigation and a case conference held. Specialist Police examine the scene and bring photographs and witness statements for review, after which a final report is completed. AHT met these criteria: history of assault (and injuries compatible with that history) or injuries regarded as not compatible with the history provided by the end of the process described above. The diagnosis made in the final report was accepted for this review. Diagnostic outcomes were categorised as natural (birth injuries and manifestations of disease), accidental, uncertain or AHT.

New Zealand does not have mandatory reporting by law, but it has been policy within Starship Hospital since 1991. Outcomes of statutory investigation are described elsewhere. ${ }^{13} 14$

\section{Data collection}

Referrals were identified from the Te Puaruruhau database, records retrieved and data extracted. Retcam images or retinal diagrams from 2001 were reviewed by a paediatric ophthalmologist (ALV) and classified following Vinchon. ${ }^{15}$

Data included age, gender, ethnicity, 'deprivation index' (NZDep) (a validated score derived from residential address, updated every five years since 1991), ${ }^{16}$ medical conditions, history, injuries, investigations and diagnostic outcomes.
Classification of skull fracture

Skull fractures were classified from radiology and autopsy reports and review of images if necessary. 'Simple' meant linear, closed and minimally or non-depressed (depression less than full vault thickness, or $<5 \mathrm{~mm}$ in thinner skulls), including 'T'-shaped, 'L'-shaped and ' $\mathrm{Y}$ '-shaped fractures and those crossing sutures. Thus, a linear parietal fracture crossing the sagittal suture was 'simple'. 'Complex' fractures included all others: multiple, base of skull, compound, comminuted or depressed. Head impact was inferred from skull fracture, bruising or soft tissue swelling on examination or imaging. ${ }^{17}$

\section{Classification of intracranial abnormalities}

Radiology and autopsy reports were reviewed and classified as reported by the neuroradiologist or pathologist. Extra-axial haemorrhage was classified as extradural (EDH), subdural $(\mathrm{SDH})$ and subarachnoid (SAH). Cerebral parenchymal changes were classified as oedema, contusion and hypoxic ischaemic injury (HII) (parenchymal changes suggesting HII, unilateral or bilateral, in a vascular or watershed distribution with no diagnostic features of traumatic injury). Global hypoxic ischaemic injury and diffuse axonal injury were diagnosed at autopsy. ${ }^{18}$

\section{Statistical method}

To enable comparison with existing AHT literature (which mostly describes children under 2 years old), data were analysed in two age categories: under and over 2 years. Data were analysed with JMP V.10.0 software (SAS, USA). Continuous variables are presented as medians with IQR, categorical variables as counts and percentages, and the two-tailed Fisher's exact test used to compare distributions. ORs with 95\% CIs are calculated. Regression of the annual increase in referral numbers was undertaken with generalised linear modelling using the Poisson distribution, and rate of referrals compared by Poisson rate ratio. The regression lines were compared by studying the interaction of injury cause with time.

\section{RESULTS}

Records were available in 437/444 referrals (98\%). Ninety-two without skull fracture or intracranial injury were excluded. The remaining 345 cases include 44 described previously. ${ }^{13} 19$ Diagnostic outcomes were 'natural' 6 (2\%) (birth trauma, haemorrhagic disease of the newborn, hydrocephalus, epilepsy, haemophilia), uncertain 37 (11\%), accidental 96 (28\%) and AHT 206 (60\%).

\section{Referral numbers}

Referrals increased markedly over time: 88 in the first decade and 257 in the second. Referrals increased from 6 in 1991 to 33 in 2010, whereas the child population growth in Auckland was 37\% (224 000-306 000, Poisson rate ratio $=4.8,95 \% \mathrm{CI}$ 2.0 to $13.8, \mathrm{p}<0.001$ ) (figure 1 ). There was no change in the proportion of referrals from outside Auckland (23\% in the first decade, 26\% in the second, $\mathrm{p}=0.67)$. Accidental cases and AHT increased together (comparison of regression lines, $p=0.11$ ). There was no significant change in the proportion of diagnostic outcomes over time $(\mathrm{p}=0.21)$.

\section{Demographics}

Most cases (257/345, 74\%) came from Auckland. Ages ranged from 6 days to 13 years (median 7 months, IQR 3-15 months). In those over 2 years $(52 / 345,15 \%)$, the median age was 3 years (IQR 2-5 years). 
Figure 1 Annual number of children referred to Starship Hospital child protection team with skull fracture and/or intracranial injuries diagnosed accidental or abusive head trauma from 1991 to 2010.

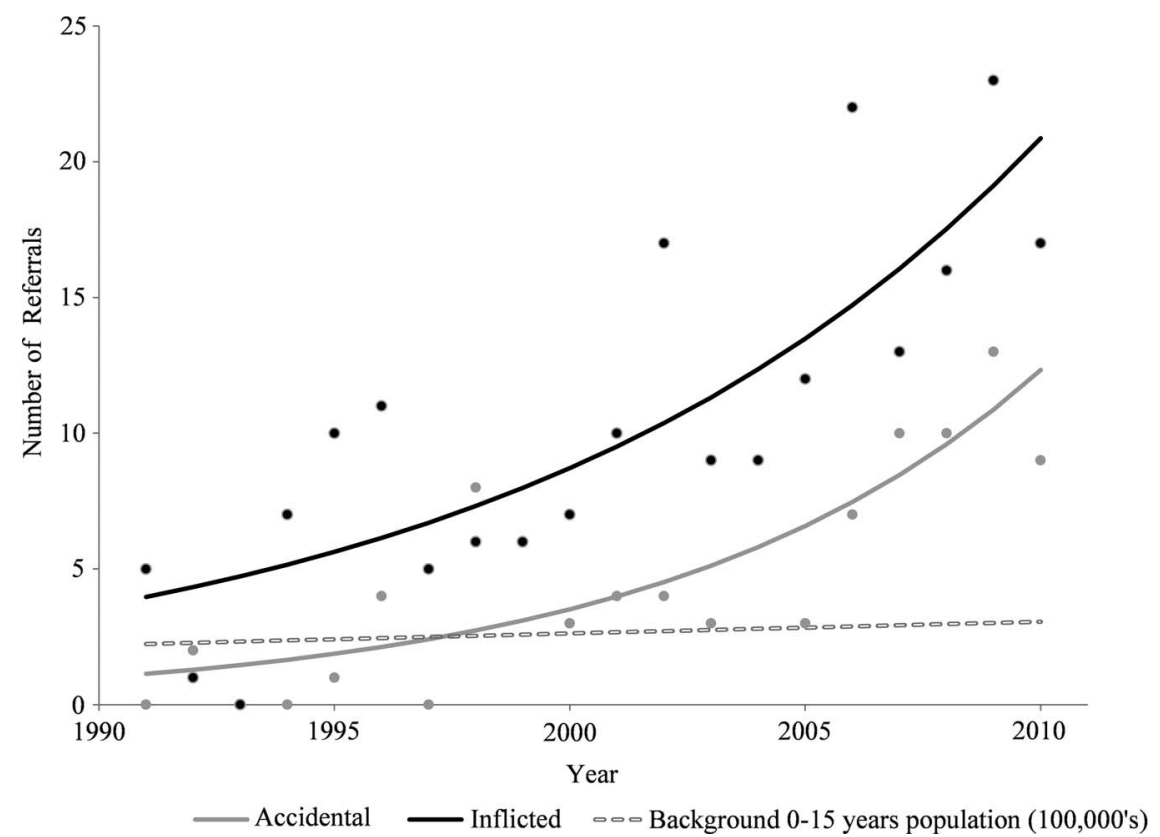

Table 1 summarises referral demographics in comparison to the childhood population, and the proportions diagnosed as AHT.

Children under 2 years old, males, higher degrees of deprivation and Polynesians were over-represented compared with the childhood population $(\mathrm{p}<0.001)$. Once referred, the likelihood of AHT was similar regardless of age, gender or degree of deprivation. Maori were most likely to be diagnosed with AHT $(p=0.05)$ and Pacific children least likely $(p=0.08)$. Overall, Polynesian children had an AHT rate of $61 \%$, similar to European children.

Table 2 compares the demographics within the referral population, between diagnosed accidental head injury and AHT.

Overall, cases of AHT (median 5 months, IQR 2-12) were younger than accidental cases (median 10 months, IQR 5-20),

Table 1 Demographics of children referred with skull fracture and/ or intracranial injury in comparison to the childhood population of Auckland, and the rate of abusive head trauma (AHT).

\begin{tabular}{|c|c|c|c|c|}
\hline & $\begin{array}{l}\text { Census } \\
\text { population } \\
\text { under } 15 \\
\text { years* } \\
(n=288,573)\end{array}$ & $\begin{array}{l}\text { Total } \\
\text { referred } \\
(n=345)\end{array}$ & $\begin{array}{l}\text { Rate of } \\
\text { AHT in } \\
\text { all referred } \\
\text { children } \\
(n=206)\end{array}$ & \\
\hline & N (\%) & N (\%) & N (\%) & OR $(95 \% \mathrm{Cl})^{* *}$ \\
\hline Under 2 years & $38,481(13)$ & $293(85)$ & $180(61)$ & $1.6(0.8-3.0)$ \\
\hline Over 2 years & $250,092(87)$ & $52(15)$ & $26(50)$ & \\
\hline Male & $147,840(51)$ & $222(64)$ & 127 (57) & $0.7(0.5-1.2)$ \\
\hline Female & $140,733(49)$ & $123(36)$ & 79 (64) & \\
\hline $\begin{array}{l}\text { Higher } \\
\text { deprivationt }\end{array}$ & $154,493(54)$ & $273(79)$ & $165(60)$ & $1.2(0.7-2.0)$ \\
\hline $\begin{array}{l}\text { Lower } \\
\text { deprivationt }\end{array}$ & $134,080(46)$ & $72(21)$ & 41 (57) & \\
\hline Maori & $50,718(18)$ & 161 (47) & 115 (71) & $1.8(1.0-3.4)$ \\
\hline Pacific & $56,136(19)$ & $91(26)$ & $39(43)$ & $0.6(0.3-1.1)$ \\
\hline European/other & $131,849(46)$ & $73(21)$ & $42(58)$ & Ref. \\
\hline Asian & 49,870 (17) & $20(6)$ & $10(50)$ & $0.7(0.2-2.3)$ \\
\hline
\end{tabular}

$\mathrm{p}<0.001$, although over 2 years old, cases of AHT (median 3 years, IQR 2-5) were similar in age to accidental cases (median 3 years, IQR 2-5), $\mathrm{p}=0.51$.

The likelihood of a diagnosis of AHT was similar across gender, deprivation index or European/Asian/Pacific ethnicity, but higher for Maori ethnicity. As a proportion of diagnostic outcomes, Maori comprised 27/96 accidental injuries (28\%) compared with 115/206 cases of AHT (56\%), p $<0.001$, whereas Pacific children comprised 39/96 accidental injuries (41\%) compared with 39/206 cases of AHT (19\%), p<0.001.

\section{Injuries}

Of 203 children with SDH, 71 (35\%) had no skull fracture or other intracranial abnormality, whether the cause was accidental $(8 / 27,30 \%)$ or AHT $(63 / 176,36 \%)$.

Of 206 children with AHT, 176 (85\%) had SDH. Of 30 without SDH, 17 had other intracranial injuries $(15 / 17$ had

Table 2 Comparison between the demographics of children referred with skull fracture and/or intracranial injury whose injuries were diagnosed as accidental or abusive head trauma (AHT)

\begin{tabular}{|c|c|c|c|}
\hline & $\begin{array}{l}\text { Accidental } \\
\mathrm{N}(\%)\end{array}$ & $\begin{array}{l}\text { AHT } \\
\mathrm{N}(\%)\end{array}$ & OR $(95 \% \mathrm{Cl}) \dagger$ \\
\hline All & $96(32)$ & $206(68)$ & \\
\hline Under 2 years & $75(29)$ & $180(71)$ & $1.9(1.0 \text { to } 3.8)^{*}$ \\
\hline Over 2 years & $21(45)$ & $26(55)$ & \\
\hline Male & $65(34)$ & $127(66)$ & $0.8(0.4$ to 1.3$)$ \\
\hline Female & $31(28)$ & $79(72)$ & \\
\hline Higher deprivation $\ddagger$ & $70(30)$ & $165(70)$ & 1.5 (0.8 to 2.7$)$ \\
\hline Lower deprivation‡ & $26(39)$ & $41(61)$ & \\
\hline Maori & $27(19)$ & $115(81)$ & $2.4(1.2 \text { to } 4.9)^{* *}$ \\
\hline Pacific & $39(50)$ & $39(50)$ & $0.6(0.3$ to 1.2$)$ \\
\hline European/other & $24(36)$ & $42(64)$ & Ref. \\
\hline Asian & $6(38)$ & $10(63)$ & $1.0(0.3$ to 3.6$)$ \\
\hline
\end{tabular}


skull fractures, 10/15 complex) and 13 had skull fractures (4/13 complex) without intracranial injury. In these 13 , other data included skeletal fractures (6), bruises (4), traumatic gastric perforation (1), two skull fractures (old and acute) (1) and a history of being thrown against a wall (1).

Some relationships between injury types and diagnosis applied to all ages (table 3). SAH did not differ significantly between accidental head injury and AHT. Long bone fractures were more common in AHT. Rib fractures were seen only in AHT. Children with AHT were more likely to die than those with accidental head injury, although the mortality was higher over 2 years old (10/26 cases of AHT, 38\%) than under 2 years old (19/180 cases of AHT, $11 \%$ ), OR=5.3 (95\% CI 2.1 to 13.3$), \mathrm{p}<0.001$.
Some relationships varied with age. Under 2 years, evidence of impact, skull fracture and EDH were significantly associated with accidental head injury. Intracranial injury, SDH, HII and $\mathrm{RH}$ were significantly associated with AHT. Over 2 years, these associations were no longer significant. Among intracranial injuries in children over 2 years, cerebral contusion and oedema rather than SDH and HII had the highest OR for AHT, although these were not statistically significant.

Table 4 compares skull fractures by diagnostic outcome. Simple fractures were common, but in general the type or location did not differ significantly between accidental injury and AHT, with two exceptions. In children under 2 years old, simple parietal fractures were more common in accidental injury,

Table 3 Types of injury in children referred with skull fracture and/or intracranial injury whose injuries were diagnosed as accidental or abusive head trauma (AHT), by age

\begin{tabular}{|c|c|c|c|c|c|c|c|c|}
\hline & & \multirow{2}{*}{$\begin{array}{l}\text { All accidental } \\
\text { and AHT } \\
\mathrm{N}\end{array}$} & \multicolumn{3}{|c|}{ Under 2 years old } & \multicolumn{3}{|c|}{ Over 2 years old } \\
\hline & & & $\begin{array}{l}\text { Accidental } \\
\mathrm{N}(\%)\end{array}$ & $\begin{array}{l}\text { AHT } \\
\mathrm{N}(\%)\end{array}$ & OR $(95 \%$ Cl)† & $\begin{array}{l}\text { Accidental } \\
\mathrm{N}(\%)\end{array}$ & $\begin{array}{l}\text { AHT } \\
\mathrm{N}(\%)\end{array}$ & OR $(95 \% \mathrm{Cl}) \dagger$ \\
\hline All & & 302 & $75(29)$ & $180(71)$ & & $21(45)$ & $26(55)$ & \\
\hline \multirow[t]{2}{*}{ Any head impact } & Yes & 201 & $66(41)$ & $96(59)$ & $0.2(0.06 \text { to } 0.3)^{* *}$ & $15(38)$ & $24(62)$ & 4.8 (0.7 to 52.8$)$ \\
\hline & No & & $9(10)$ & $84(90)$ & & $6(75)$ & $2(25)$ & \\
\hline \multirow[t]{2}{*}{ Skull fracture } & Yes & 147 & $62(52)$ & $57(48)$ & $0.1(0.05 \text { to } 0.2)^{* *}$ & $15(54)$ & $13(46)$ & $0.4(0.1$ to 1.6$)$ \\
\hline & No & & $13(10)$ & $123(90)$ & & $6(32)$ & $13(68)$ & \\
\hline \multirow[t]{2}{*}{ Intracranial injury } & Yes & 246 & $38(18)$ & $170(82)$ & $16.6(7.2 \text { to } 40.1)^{* *}$ & $15(39)$ & $23(61)$ & 3.1 (0.5 to 21.4 ) \\
\hline & No & & 37 (79) & $10(21)$ & & $6(67)$ & $3(33)$ & \\
\hline \multirow[t]{2}{*}{ EDH } & Yes & 20 & $8(73)$ & $3(27)$ & $0.1(0.02 \text { to } 0.6)^{*}$ & $6(67)$ & $3(33)$ & 0.3 (0.05 to 1.9 ) \\
\hline & No & & $67(27)$ & $177(73)$ & & $15(39)$ & $23(61)$ & \\
\hline \multirow[t]{2}{*}{ SDH } & Yes & 203 & $19(11)$ & $160(89)$ & $23.6(11.1 \text { to } 50.4)^{* *}$ & $8(33)$ & $16(67)$ & $2.6(0.7$ to 10.0$)$ \\
\hline & No & & $56(74)$ & $20(26)$ & & $13(57)$ & $10(43)$ & \\
\hline \multirow[t]{2}{*}{ SAH } & Yes & 51 & $10(22)$ & $35(78)$ & $1.6(0.7$ to 3.8$)$ & $2(33)$ & $4(67)$ & 1.7 (0.2 to 20.9$)$ \\
\hline & No & & $65(31)$ & $145(69)$ & & $19(46)$ & $22(54)$ & \\
\hline \multirow[t]{2}{*}{ Contusion } & Yes & 65 & $11(22)$ & $40(78)$ & 1.7 (0.8 to 3.8 ) & $3(21)$ & $11(79)$ & 4.4 (0.9 to 28.1$)$ \\
\hline & No & & 64 (31) & $140(69)$ & & $18(55)$ & $15(45)$ & \\
\hline \multirow[t]{2}{*}{ HII } & Yes & 46 & $1(3)$ & 38 (97) & $19.8(3.2 \text { to } 813)^{\star *}$ & $2(29)$ & $5(71)$ & $2.3(0.3$ to 26.0$)$ \\
\hline & No & & 74 (34) & $142(66)$ & & $19(48)$ & $21(53)$ & \\
\hline \multirow[t]{2}{*}{ GHII§ } & Yes & 12 & $0(0)$ & $10(100)$ & $\propto(1.0 \text { to } \propto)^{*}$ & $0(0)$ & $2(100)$ & $\propto(0.2$ to $\propto)$ \\
\hline & No & & $75(31)$ & $170(69)$ & & $21(47)$ & $24(53)$ & \\
\hline \multirow[t]{2}{*}{ DAI§ } & Yes & 10 & $0(0)$ & $8(100)$ & $\propto(0.7$ to $\propto)$ & $0(0)$ & $2(100)$ & $\propto(0.2$ to $\propto)$ \\
\hline & No & & $75(30)$ & $172(70)$ & & $21(47)$ & $24(53)$ & \\
\hline \multirow[t]{2}{*}{ Oedema } & Yes & 24 & $1(8)$ & $12(92)$ & 5.3 (0.8 to 229$)$ & $2(18)$ & $9(82)$ & 5.0 (0.8 to 52.5$)$ \\
\hline & No & & $74(31)$ & $168(69)$ & & $19(53)$ & $17(47)$ & \\
\hline \multirow[t]{2}{*}{ RHๆ } & Yes & $132 / 252$ & $3(3)$ & 117 (98) & $28.6(8.5 \text { to } 147)^{* *}$ & $3(25)$ & $9(75)$ & 3.0 (0.5 to 22.9$)$ \\
\hline & No & & $44(42)$ & $60(58)$ & & $8(50)$ & $8(50)$ & \\
\hline \multirow[t]{2}{*}{ Long bone fracturet† } & Yes & $46 / 288$ & $3(8)$ & $33(92)$ & $4.6(1.3 \text { to } 24.0)^{*}$ & $1(10)$ & $9(90)$ & $10.6(1.2 \text { to } 487)^{*}$ \\
\hline & No & & $60(29)$ & $145(71)$ & & $20(54)$ & $17(46)$ & \\
\hline \multirow[t]{2}{*}{ Rib fracturet† } & Yes & $29 / 288$ & $0(0)$ & $27(100)$ & $\propto(2.7 \text { to } \propto)^{* *}$ & $0(0)$ & $2(100)$ & $\propto(0.2$ to $\propto)$ \\
\hline & No & & $63(29)$ & $151(71)$ & & $21(47)$ & $24(53)$ & \\
\hline \multirow[t]{2}{*}{ Other fracturet† } & Yes & $8 / 288$ & $0(0)$ & $4(100)$ & $\propto(0.2$ to $\propto)$ & $1(25)$ & $3(75)$ & $2.6(0.2$ to 144$)$ \\
\hline & No & & $63(27)$ & $174(73)$ & & $20(47)$ & $23(53)$ & \\
\hline \multirow[t]{2}{*}{ Internal injury } & Yes & 10 & $0(0)$ & $4(100)$ & $\propto(0.3$ to $\propto)$ & $1(17)$ & $5(83)$ & 4.8 (0.5 to 236$)$ \\
\hline & No & & $75(30)$ & $176(70)$ & & $20(49)$ & $21(51)$ & \\
\hline \multirow[t]{2}{*}{ Death } & Yes & 30 & $1(5)$ & $19(95)$ & $8.7(1.3 \text { to } 367)^{*}$ & $0(0)$ & $10(100)$ & $\propto(2.7 \text { to } \propto)^{* *}$ \\
\hline & No & & 74 (31) & $161(69)$ & & $21(57)$ & $16(43)$ & \\
\hline
\end{tabular}

${ }^{*} \mathrm{p}<0.05,{ }^{* *} \mathrm{p}<0.001$, Fisher's exact test.

tOR with $95 \% \mathrm{Cl}$, for the odds of AHT versus accidental.

‡Excluding cases later classified as GHII or DAI at autopsy.

§Autopsy diagnosis.

१The denominator is the 252 children who had dilated fundoscopy.

t+The denominator is 241 children under 2 years old who had skeletal survey plus all 47 children over 2 years old.

DAl, diffuse axonal injury; GHII, global hypoxic ischaemic injury; HII, hypoxic ischaemic injury; RH, retinal haemorrhage. 
Table 4 Types of skull fracture in children referred with skull fracture and/or intracranial injury whose injuries were diagnosed as accidental or abusive head trauma (AHT), by age

\begin{tabular}{|c|c|c|c|c|c|c|c|c|}
\hline & & \multirow{2}{*}{$\begin{array}{l}\text { All accidental } \\
\text { and } \mathrm{AHT} \\
\mathrm{N}\end{array}$} & \multicolumn{3}{|c|}{ Under 2 years old } & \multicolumn{3}{|c|}{ Over 2 years old } \\
\hline & & & $\begin{array}{l}\text { Accidental } \\
\mathrm{N}(\%)\end{array}$ & $\begin{array}{l}\text { AHT } \\
\text { N (\%) }\end{array}$ & OR $(95 \% \mathrm{Cl}) \dagger$ & $\begin{array}{l}\text { Accidental } \\
\mathrm{N}(\%)\end{array}$ & $\begin{array}{l}\text { AHT } \\
\text { N (\%) }\end{array}$ & OR $(95 \% \mathrm{Cl}) \dagger$ \\
\hline \multicolumn{2}{|l|}{ All skull fractures } & 147 & $62(52)$ & $57(48)$ & & $15(54)$ & $13(46)$ & \\
\hline \multirow[t]{2}{*}{ All simple } & Yes & 90 & $45(58)$ & $32(42)$ & $0.5(0.2$ to 1.1$)$ & $9(69)$ & $4(31)$ & 0.3 (0.05 to 1.8$)$ \\
\hline & No & & $17(40)$ & $25(60)$ & & $6(40)$ & $9(60)$ & \\
\hline \multirow[t]{2}{*}{ Simple with ICI } & Yes & 51 & $19(43)$ & $25(57)$ & $1.8(0.8$ to 4.0$)$ & $5(71)$ & $2(29)$ & $0.4(0.03$ to 3.0$)$ \\
\hline & No & & $43(57)$ & $32(43)$ & & $10(48)$ & $11(52)$ & \\
\hline \multirow[t]{2}{*}{ Parietal } & Yes & 61 & $37(65)$ & $20(35)$ & $0.4(0.2 \text { to } 0.8)^{*}$ & $4(100)$ & $0(0)$ & 0 (0 to 1.6$)$ \\
\hline & No & & $25(40)$ & $37(60)$ & & $11(46)$ & $13(54)$ & \\
\hline \multirow[t]{2}{*}{ Occipital } & Yes & 17 & $6(46)$ & 7 (54) & $1.3(0.3$ to 5.0$)$ & $1(25)$ & $3(75)$ & $4.2(0.3$ to 236$)$ \\
\hline & No & & $56(53)$ & $50(47)$ & & $14(58)$ & $10(42)$ & \\
\hline \multirow[t]{2}{*}{ Temporal } & Yes & 2 & $1(50)$ & $1(50)$ & $1.1(0.01$ to 86.9$)$ & 0 & 0 & - \\
\hline & No & & $61(52)$ & $56(48)$ & & $15(54)$ & $13(46)$ & \\
\hline \multirow[t]{2}{*}{ Frontal } & Yes & 2 & $0(0)$ & $2(100)$ & $\propto(0.2$ to $\propto)$ & 0 & 0 & - \\
\hline & No & & $62(53)$ & $55(47)$ & & $15(54)$ & $13(46)$ & \\
\hline \multirow[t]{2}{*}{ Otherł } & Yes & 8 & $1(33)$ & $2(67)$ & $2.2(0.1$ to 133$)$ & $4(80)$ & $1(20)$ & 0.2 (0.0 to 2.9 ) \\
\hline & No & & $61(53)$ & $55(47)$ & & $11(48)$ & $12(52)$ & \\
\hline \multirow[t]{2}{*}{ All complex } & Yes & 57 & $17(40)$ & $25(60)$ & 2.1 (0.9 to 4.8$)$ & $6(40)$ & $9(60)$ & $3.4(0.6$ to 21.9$)$ \\
\hline & No & & $45(58)$ & $32(42)$ & & $9(69)$ & $4(31)$ & \\
\hline \multirow[t]{2}{*}{ Complex with ICI } & Yes & 40 & $6(21)$ & $22(79)$ & $5.8(2.0 \text { to } 19.2)^{* *}$ & $4(33)$ & $8(67)$ & $4.4(0.7$ to 29.5$)$ \\
\hline & No & & $56(62)$ & $35(38)$ & & $11(69)$ & $5(31)$ & \\
\hline \multirow[t]{2}{*}{ Multiple } & Yes & 19 & 7 (39) & $11(61)$ & $1.9(0.6$ to 6.2$)$ & $0(0)$ & $1(100)$ & $\propto(0.03$ to $\propto)$ \\
\hline & No & & $55(54)$ & $46(46)$ & & $15(56)$ & $12(44)$ & \\
\hline \multirow[t]{2}{*}{ BOS } & Yes & 18 & $4(50)$ & $4(50)$ & $1.1(0.2$ to 6.2$)$ & $4(40)$ & $6(60)$ & $2.4(0.4$ to 15.5$)$ \\
\hline & No & & $58(52)$ & $53(48)$ & & $11(61)$ & 7 (39) & \\
\hline \multirow[t]{2}{*}{ Comminuted } & Yes & 11 & $3(30)$ & $7(70)$ & 2.8 (0.6 to 17.2$)$ & $1(100)$ & $0(0)$ & $0(0$ to 45.0$)$ \\
\hline & No & & $59(54)$ & $50(46)$ & & $14(52)$ & $13(48)$ & \\
\hline \multirow[t]{2}{*}{ Depressed } & Yes & 5 & $2(50)$ & $2(50)$ & 1.1 (0.08 to 15.5$)$ & $0(0)$ & $1(100)$ & $\propto(0.03$ to $\propto)$ \\
\hline & No & & $60(52)$ & $55(48)$ & & $15(56)$ & $12(44)$ & \\
\hline \multirow[t]{2}{*}{ Compound } & Yes & 4 & $1(50)$ & $1(50)$ & 1.1 (0.01 to 86.9 ) & $1(50)$ & $1(50)$ & $1.2(0.01$ to 98.0$)$ \\
\hline & No & & $61(52)$ & $56(48)$ & & $14(54)$ & $12(46)$ & \\
\hline
\end{tabular}

${ }^{*} p<0.05,{ }^{* *} p<0.001$, Fisher's exact test.

tOR with $95 \% \mathrm{Cl}$, for the odds of AHT versus accidental.

$\ddagger^{\prime}$ Other' includes three occipitoparietal, two temporoparietal, one frontoparietal and two sutural.

$\mathrm{BOS}$, base of skull; ICl, intracranial injury.

whereas complex skull fractures with intracranial injury were more common in AHT.

Also, 30 of 39 children with simple skull fractures and no intracranial injury were diagnosed as accidental (77\%), typically presenting with a lump on the head of a well toddler (median age 11 months, IQR 7-16).

\section{Radiology and ophthalmoscopy}

CT head was performed in all 302 children, MRI in 149 and skeletal survey in 274: 241/255 (95\%) under 2 years and 33/47 $(70 \%)$ over 2 . Skeletal survey was positive in $64 / 274$ children (23\%): 54/241 (22\%) under 2 years and 10/33 (30\%) over 2.

From 2001, Retcam photographs or diagrams enabled classification of $90 / 99$ cases with RH (91\%). RH was bilateral in 69/90 (77\%). At worst, it was grade 3 (severe) in 50 children, of whom 39 had retinoschisis and one choroidal rupture; grade 2 (moderate) in 24 and grade 1 (mild) in 16. Six accidental cases had RH (table 5).

\section{History of injury}

Table 6 compares the type of history provided. A history of a fall was common in accidental head injuries, and 'no history of trauma' common in AHT. However, a history of a fall was also provided in many cases of AHT and no history of trauma in some cases of accidental head injury: for example, a baby found on the floor beside a post-ictal parent, and a toddler found with grazes suggesting a possible side-swipe by a car. A history of assault was uncommon, but more common over 2 years old $(13 / 47,28 \%$ vs $15 / 255,6 \%, p<0.001)$. Under 2 , mechanisms divulged included shaking, hitting and kicking. Over 2, all mechanisms divulged involved impact: swung or thrown against a wall, beaten, kicked or struck with an object.

\section{DISCUSSION}

This is one of the largest published series of children from a single institution comprehensively evaluated for suspected AHT.

The increase in referrals is striking and suggests increasing incidence. ${ }^{18}$ Over the same period, child abuse has received sustained public attention with exponential increases in statutory notifications. ${ }^{20}$ This may have lowered referral thresholds, but there was no decrease in the ratio of AHT. Retcam photography improved the quality of documentation and MRI improved the description of intracranial abnormalities, but the consistent 
Table 5 Description of retinal haemorrhages in children with accidental head injuries

\begin{tabular}{|c|c|c|c|c|}
\hline $\begin{array}{l}\text { Age } \\
\text { (years) }\end{array}$ & Accident & Type of haemorrhages & Grade* & Other findingst \\
\hline Under 2 & Asphyxiated & Bilateral. Scattered intra-retinal, posterior pole and mid-periphery, $50 \%$ white-centred & 1 & $\begin{array}{l}\text { SAH, HII, cerebral oedema, cortical } \\
\text { venous thrombosis. No SDH }\end{array}$ \\
\hline Over 2 & $\begin{array}{l}\text { Knocked out by } \\
\text { falling object }\end{array}$ & $\begin{array}{l}\text { Bilateral. Pre-retinal and deeper intra-retinal, including flame-shaped, white-centred } \\
\text { and deeper blot retinal haemorrhages, posterior pole }\end{array}$ & 2 & Bilateral SAH \\
\hline Over 2 & $\begin{array}{l}\text { Fell } 1-2 \mathrm{~m} \text { from play } \\
\text { equipment }\end{array}$ & Bilateral. Numerous intra-retinal, posterior pole and mid-peripheral & 2 & Unilateral SDH \\
\hline Under 2 & $\begin{array}{l}\text { Fell } 1.35 \mathrm{~m} \text {, striking } \\
\text { occiput }\end{array}$ & $\begin{array}{l}\text { Bilateral. Several scattered blot haemorrhages around the posterior pole with } \\
\text { occasional blot haemorrhages in periphery }\end{array}$ & 2 & $\begin{array}{l}\text { Occipital skull fracture, unilateral } \\
\text { SDH }\end{array}$ \\
\hline Over 2 & $\begin{array}{l}\text { Fell } 1.5 \mathrm{~m} \text { from play } \\
\text { equipment }\end{array}$ & $\begin{array}{l}\text { Unilateral. Occasional small flame haemorrhages, posterior pole. } 1 \text { small blot } \\
\text { haemorrhage with a white centre, } 2 \text { small round pre-retinal adjacent to the central } \\
\text { macula }\end{array}$ & 1 & $\begin{array}{l}\text { Unilateral SDH and hemispheric } \\
\text { infarction }\end{array}$ \\
\hline Under 2 & Fell $2 \mathrm{~m}$ & Unilateral. Two small intra-retinal haemorrhages, posterior pole & 1 & $\begin{array}{l}\text { Parietal skull fracture, unilateral } \\
\text { SDH }\end{array}$ \\
\hline
\end{tabular}

${ }^{*}$ Retinal haemorrhages graded following Vinchon. ${ }^{15}$

tIncluding negative skeletal surveys in five children $\leq 2$ years old.

HII, hypoxic ischaemic injury; SAH, subarachnoid haemorrhage; SDH, subdural haemorrhage.

diagnostic proportions over time suggest that these technologies did not change diagnostic outcomes.

Referral demographics were consistent with the literature: mostly under 2, mostly more deprived and mostly male. ${ }^{21-23}$ Most referrals shared these factors, and they did not distinguish accidental injuries from AHT. Once referred, children without those 'risk factors' were just as likely to justify a diagnosis of AHT. Clinicians assessing children with head injuries, or with symptoms for which a head injury is one possible diagnosis, are at risk of 'a subtle bias in decision making' ${ }^{4}$ based on race or socio-economic status. ${ }^{4} 2425$ Our findings re-emphasise that screening based on such demographic 'risk factors' would be unsafe.

Maori were over-represented in referrals and in diagnosed AHT. $^{26}$ There is conflicting literature on the relationship between AHT and ethnicity, ${ }^{3} 2127$ but our finding is consistent with the social adversity experienced by many colonised indigenous peoples. ${ }^{28-30}$ Ethnic bias in the diagnosis of AHT seems unlikely in our cohort, given the differential diagnostic ratios for Maori and Pacific children and the fact that, once referred,
Europeans were more likely than not to be diagnosed with AHT. Ethnic bias in recognition or referral of inflicted injury is reported ${ }^{4} 3132$ and is one possible interpretation of our finding that Pacific children were more likely to be referred, but less likely to be diagnosed with AHT. Another interpretation is that Pacific children are more likely to sustain accidental injury. ${ }^{3} 33$ Both possibilities raise important questions that we plan to study further.

Falls are often proposed to explain AHT. ${ }^{34}$ In our cohort, half of those referred with head injury from a reported fall were diagnosed with AHT. Falls are also the leading cause of accidental head injury. ${ }^{33}$ We suggest that most genuine accidental falls were appropriately identified at presentation and those referred were a high-risk population. The fact that our rate of positive skeletal surveys in children over 2 years was as high as in younger children also suggests that primary clinicians were appropriately identifying older children at risk.

It is well known that often no history of trauma is provided in a child with AHT. ${ }^{5}{ }^{35}$ However, as our data show, this must always be interpreted in context, with attention to the child's

Table 6 Type of history given in children referred with skull fracture and/or intracranial injury whose injuries were diagnosed as accidental or abusive head trauma (AHT), by age

\begin{tabular}{|c|c|c|c|c|c|c|c|c|}
\hline & & \multirow{2}{*}{$\begin{array}{l}\text { All accidental } \\
\text { and AHT } \\
\mathrm{N}\end{array}$} & \multicolumn{3}{|c|}{ Under 2 years old } & \multicolumn{3}{|c|}{ Over 2 years old } \\
\hline & & & $\begin{array}{l}\text { Accidental } \\
\mathrm{N}(\%)\end{array}$ & $\begin{array}{l}\text { AHT } \\
\text { N (\%) }\end{array}$ & OR $(95 \% \mathrm{Cl}) \dagger$ & $\begin{array}{l}\text { Accidental } \\
\mathrm{N}(\%)\end{array}$ & $\begin{array}{l}\text { AHT } \\
\text { N (\%) }\end{array}$ & OR $(95 \% \mathrm{Cl}) \dagger$ \\
\hline All & & 302 & $75(29)$ & $180(71)$ & & $21(45)$ & $26(55)$ & \\
\hline \multirow[t]{2}{*}{ Fall } & Yes & 151 & $59(47)$ & $67(53)$ & $0.2(0.08 \text { to } 0.3)^{* *}$ & $15(60)$ & $10(40)$ & $0.3(0.06 \text { to } 1.0)^{*}$ \\
\hline & No & & $16(12)$ & $113(88)$ & & $6(27)$ & $16(73)$ & \\
\hline \multirow[t]{2}{*}{ No history of trauma } & Yes & 103 & $10(10)$ & $88(90)$ & $6.2(2.9 \text { to } 14.4)^{* *}$ & $2(40)$ & $3(60)$ & $1.2(0.1$ to 16.2$)$ \\
\hline & No & & $65(41)$ & $92(59)$ & & $19(45)$ & $23(55)$ & \\
\hline \multirow[t]{2}{*}{ Assault } & Yes & 28 & $0(0)$ & $15(100)$ & $\propto(1.6 \text { to } \propto)^{*}$ & $0(0)$ & $13(100)$ & $\propto(3.9 \text { to } \propto)^{* *}$ \\
\hline & No & & $75(31)$ & $165(69)$ & & $21(62)$ & $13(38)$ & \\
\hline \multirow[t]{2}{*}{ Blunt force trauma } & Yes & 5 & $3(100)$ & $0(0)$ & $0(0 \text { to } 1.0)^{*}$ & $2(100)$ & $0(0)$ & 0 (0 to 4.2$)$ \\
\hline & No & & $72(29)$ & $180(71)$ & & $19(42)$ & $26(58)$ & \\
\hline \multirow[t]{2}{*}{ Other } & Yes & 15 & $3(23)$ & $10(77)$ & $1.4(0.3$ to 8.2$)$ & $2(100)$ & $0(0)$ & 0 (0 to 4.2$)$ \\
\hline & No & & $72(30)$ & $170(70)$ & & $19(42)$ & $26(58)$ & \\
\hline
\end{tabular}

${ }^{*} \mathrm{p}<0.05,{ }^{* *} \mathrm{p}<0.001$, Fisher's exact test.

tOR with $95 \% \mathrm{Cl}(95 \% \mathrm{Cl})$, for the odds of AHT versus Accidental. 
developmental abilities (such as independent mobility) and other circumstances that may support an accidental explanation.

Our data on AHT are consistent with the literature. There is no feature that is pathognomonic, but combinations of features enable accurate diagnosis. Much of the literature on AHT focuses on children under 2 years. In that age group, we saw the typical associations between SDH, HII, RH, extra-cranial fractures and AHT, and between skull fracture, EDH and accidental injury. ${ }^{35} 36$ However, not all AHT causes SDH, and studies using $\mathrm{SDH}$ as their sole search criterion will underestimate the prevalence of AHT. Cerebral contusions are seldom discussed, but our experience is consistent with other studies describing prevalence in AHT of 10-16\%. ${ }^{37} 38$

Our findings are also consistent with existing literature that neither type of skull fracture nor the presence or absence of soft tissue evidence of impact to the head reliably distinguish accidental head injury from AHT. ${ }^{39} 40$

We found intriguing differences in the pattern of injury in older children. When interpreting these data, it must be remembered that our accidental cases were a selected population. Most serious accidental head trauma occurs in older children who are not referred because the circumstances are obvious (motor vehicle accidents, pedestrian drive-overs, major falls). It is likely, therefore, that major accidental impact injuries were underrepresented in our study. Conversely, because severely injured children were more likely to be transferred, the proportion with life-threatening AHT is probably greater in this study than in children presenting to non-referral centres.

Nevertheless, the pattern of injury appeared to differ between younger and older cases of AHT. The obvious inference, from the mechanisms divulged and the injuries seen, is that in older children AHT typically requires impact to the head. They are heavier and more difficult to shake, biologically less vulnerable to shaking and more mobile. It is more likely that they will be punched, kicked or thrown. It would not be surprising if such mechanisms have a high risk of a fatal outcome. Our findings are consistent with a recent multicentre study of AHT describing significant relationships between age (>12 months old), intraparenchymal haemorrhage, cerebral oedema and mortality. ${ }^{41}$

Our study reaffirms that in some cases the diagnosis remains uncertain no matter how thorough the investigation. Some studies make this explicit ${ }^{22} 264243$ but most do not. It is important that such data are made routinely available. They may be helpful both to clinicians working in child protection when comparing their diagnostic outcomes with the scientific literature and to families who may fear that they are engaged in a process with no room for uncertainty.

\section{LIMITATIONS}

A limitation of this study is that our accidental cases were a selected subset of all children admitted with head injuries. In addition, this was an audit of practice over 20 years. As such, data were not collected prospectively and not all procedures (such as MRI, fundoscopy and skeletal survey) were undertaken on all children. The assessment process evolved over time towards earlier and closer collaboration with the statutory authorities. Nevertheless, there has been consistency in key personnel and clinical approach since 1991 and our findings are consistent with the literature.

\section{CONCLUSION}

There has been a striking increase in referrals for suspected AHT with no decrease in the ratio of cases that met criteria for AHT, probably representing a true increase in incidence.
Regardless of ethnicity or socio-economic status, head-injured children referred by hospital staff are at high risk of meeting criteria for AHT. Children over 2 years old who require hospitalisation for AHT are usually injured by mechanisms involving impact to the head and are at high risk of death.

\section{Twitter Follow Andrea Vincent at @ethellini}

Acknowledgements We thank the staff of Starship Children's Hospital (especially Te Puaruruhau, the Children's Emergency Department, General Paediatrics, Paediatric Intensive Care, Paediatric Neuroservices and Paediatric Radiology) and Auckland Hospital (especially Paediatric Ophthalmology, Neuroradiology and Forensic Pathology), the New Zealand Police and Child Youth and Family (the statutory child protection agency in New Zealand) for their dedicated work over many years.

Contributors PK conceptualised and designed the study with SJ, supervised data collection, reviewed, revised and analysed the data, drafted and revised the manuscript and approved the final manuscript as submitted. SJ conceptualised and designed the study with PK, collected and analysed the data, assisted in drafting and revising the manuscript and approved the final manuscript as submitted. ALV reviewed and analysed the retinal diagrams and Retcam images, revised the manuscript and approved the final manuscript as submitted. PR provided advice on study design, carried out the statistical analyses, revised the manuscript and approved the final manuscript as submitted.

\section{Competing interests None declared.}

Ethics approval Upper South A Regional Ethics Committee, NZ Ministry of Health.

Provenance and peer review Not commissioned; externally peer reviewed.

Data sharing statement Non-identifying data in the form of an Excel spreadsheet that links basic demographics, histories, investigations, injuries and diagnostic outcomes are available to bona fide scientific researchers-for example, for the purposes of systematic review or meta-analysis.

Open Access This is an Open Access article distributed in accordance with the Creative Commons Attribution Non Commercial (CC BY-NC 4.0) license, which permits others to distribute, remix, adapt, build upon this work non-commercially, and license their derivative works on different terms, provided the original work is properly cited and the use is non-commercial. See: http://creativecommons.org/ licenses/by-nc/4.0/

\section{REFERENCES}

1 Maguire S, Mann M. Systematic reviews of bruising in relation to child abuse-what have we learnt: an overview of review updates. Evid Based Child Health 2013:8:255-63.

2 Parks S, Sugerman D, Xu L, et al. Characteristics of non-fatal abusive head trauma among children in the USA, 2003-2008: application of the CDC operational case definition to national hospital inpatient data. Inj Prev 2012;18:392-8.

3 Parks SE, Kegler SR, Annest JL, et al. Characteristics of fatal abusive head trauma among children in the USA: 2003-2007: an application of the CDC operational case definition to national vital statistics data. Inj Prev 2012;18:193-9.

4 Jenny $C$, Hymel KP, Ritzen $A$, et al. Analysis of missed cases of abusive head trauma. JAMA 1999;281:621-6.

5 Hettler J, Greenes DS. Can the initial history predict whether a child with a head injury has been abused? Pediatrics 2003;111:602-7.

6 National Society for the Prevention of Cruelty to Children. Which of you did it? Problems of achieving criminal convictions when a child dies or is seriously injured by parents or carers. London: NSPCC, 2002.

7 David TJ. Child abuse and paediatrics. J R Soc Med 2005;98:229-31.

8 Jenny C. Supporting paediatricians who work in child maltreatment. Lancet 2009;373:195-7.

9 Kemp AM. Abusive head trauma: recognition and the essential investigation. Arch Dis Child Educ Pract Ed 2011;96:202-8.

10 Glick JC, Staley K. Inflicted traumatic brain injury: advances in evaluation and collaborative diagnosis. Pediatr Neurosurg 2007;43:436-41.

11 Statistics New Zealand. 2006 Census. Wellington: Statistics New Zealand, 2014. http:/l www.stats.govt.nz/Census/2006CensusHomePage.aspx (accessed 25 Sep 2014).

12 Harper NS, Eddleman S, Lindberg DM, Investigators ES. The utility of follow-up skeletal surveys in child abuse. Pediatrics 2013;131:e672-8.

13 Kelly P, MacCormick J, Strange R. Non-accidental head injury in New Zealand: the outcome of referral to statutory authorities. Child Abuse Negl 2009;33:393-401.

14 Friedman J, Reed $\mathrm{P}$, Sharplin $\mathrm{P}$, et al. Primary prevention of pediatric abusive head trauma: a cost audit and cost-utility analysis. Child Abuse Negl 2012;36:760-70.

15 Vinchon M, Defoort-Dhellemmes S, Desurmont M, et al. Accidental and nonaccidental head injuries in infants: a prospective study. J Neurosurg 2005; 102:380-4.

16 White P, Gunston J, Salmond C, et al. Atlas of socioeconomic deprivation in New Zealand NZ Dep 2006. Wellington: Ministry of Health, 2008. 
17 John SM, Kelly P, Vincent A. Patterns of structural head injury in children younger than 3 years: a ten-year review of 519 patients. J Trauma Acute Care Surg 2013;74:276-81

18 John SM, Jones P, Kelly P, et al. Fatal pediatric head injuries: a 20-year review of cases through the Auckland coroner's office. Am J Forensic Med Pathol 2013:34:277-82.

19 Kelly P, Hayes I. Infantile subdural haematoma in Auckland, New Zealand: 1988-1998. N Z Med J 2004;117:U1047.

20 Kelly P. Corporal punishment and child maltreatment in New Zealand. Acta Paediatr 2011;100:14-20.

21 Keenan HT, Runyan DK, Marshall SW, et al. A population-based study of inflicted traumatic brain injury in young children. JAMA 2003;290:621-6.

22 Hobbs C, Childs AM, Wynne J, et al. Subdural haematoma and effusion in infancy: an epidemiological study. Arch Dis Child 2005;90:952-5.

23 Minns RA, Jones PA, Mok JY. Incidence and demography of non-accidental head injury in southeast Scotland from a national database. Am J Prev Med 2008;34: S126-33.

24 Kemp A, Coles $L$. The role of health professionals in preventing non-accidental head injury. Child Abuse Review 2003;12:374-83.

25 Sanders T, Cobley C, Coles L, et al. Factors affecting clinical referral of young children with a subdural haemorrhage to child protection agencies. Child Abuse Rev 2003;12:358-73.

26 Kelly P, Farrant B. Shaken baby syndrome in New Zealand, 2000-2002. J Paediatr Child Health 2008;44:99-107.

27 Sinal SH, Petree AR, Herman-Giddens $M$, et al. Is race or ethnicity a predictive factor in Shaken Baby Syndrome? Child Abuse Negl 2000;24:1241-6.

28 Marie D, Fergusson D, Boden J. Ethnic Identity and Exposure to Maltreatment in Childhood: Evidence from a New Zealand Birth Cohort. Soc Policy J N Z 2009;36:154-71.

29 Stanley J, Tomison A, Pocock J. Child abuse and neglect in indigenous Australian communities. In: Child abuse prevention issues, Vol 19. Melbourne: National Child Protection Clearinghouse, 2003:1-31.
30 Sotero M. A conceptual model of historical trauma: implications for public health practice and research. J Health Disparities Res Pract 2006;1:93-108.

31 Lane WG, Rubin DM, Monteith $\mathrm{R}$, et al. Racial differences in the evaluation of pediatric fractures for physical abuse. JAMA 2002;288:1603-9.

32 Wood JN, Hall M, Schilling $S$, et al. Disparities in the evaluation and diagnosis of abuse among infants with traumatic brain injury. Pediatrics 2010;126:408-14.

33 Feigin VL, Theadom A, Barker-Collo $\mathrm{S}$, et al. Incidence of traumatic brain injury in New Zealand: a population-based study. Lancet Neurol 2013;12:53-64.

34 Ettaro L, Berger RP, Songer T. Abusive head trauma in young children: characteristics and medical charges in a hospitalized population. Child Abuse Negl 2004;28:1099-111.

35 Maguire S, Pickerd N, Farewell D, et al. Which clinical features distinguish inflicted from non-inflicted brain injury? A systematic review. Arch Dis Child 2009;94:860-7.

36 Kemp AM, Jaspan T, Griffiths J. Neuro-imaging. What neuroradiological features distinguish abusive from non-abusive head trauma? A systematic review. Arch Dis Child 2011;96:1103-12.

37 Keenan HT, Runyan DK, Marshall SW, et al. A population-based comparison of clinical and outcome characteristics of young children with serious inflicted and noninflicted traumatic brain injury. Pediatrics 2004;114:633-9.

38 Reece R, Sege R. Childhood head injuries. Arch Pediatric Adolesc Med 2000:154:11-15.

39 Kemp AM, Dunstan F, Harrison S, et al. Patterns of skeletal fractures in child abuse: systematic review. BMJ 2008;337:a1518.

40 Maguire SA, Kemp AM, Lumb RC, et al. Estimating the probability of abusive head trauma: a pooled analysis. Pediatrics 2011;128:e550-64.

41 Shein SL, Bell MJ, Kochanek PM, et al. Risk factors for mortality in children with abusive head trauma. J Pediatr 2012;161:716-22 e1.

42 Feldman KW, Bethel R, Shugerman RP, et al. The cause of infant and toddler subdural hemorrhage: a prospective study. Pediatrics 2001;108:636-46.

43 Myhre MC, Grogaard JB, Dyb GA, et al. Traumatic head injury in infants and toddlers. Acta Paediatr 2007:96:1159-63. 